DOI: 10.24234/wisdom.v17i1.452

Iryna GRABOVSKA,

Tetiana TALKO,

Svitlana KAHAMLYK,

Maryna HONCHARENKO,

Yuliia SIEROVA

\title{
POLITICAL IDEAS PRESENTED BY LEADERS OF \\ THE “NEW GENERATION” CHARISMATIC MOVEMENT REGARDING THE FORMATION OF POSTSECULAR TRENDS IN UKRAINE
}

\begin{abstract}
The article is devoted to analysing political ideas presented by leaders of Ukrainian communities of the International New Religious Movement "New Generation" related to the aggravation of conflict in the Ukrainian community's public life within deepening post-secular trends. The negative attitude of a particular part of the Ukrainian student community towards charismatic leaders' political strategies was identified in the analysis process. It was based on the criticism of personal qualities and manipulating practices employed by the movement leaders.

The term "political theology" is used by the Ukrainian "New Generation" charismatic leaders to outline and describe the nature of the movement's political ideology. It is based on ideas of the "New World Order" by O. Lediaev and some Christian extremism features. Criticizing the "New Generation" leaders' theocratic ideas, the authors focused on their influence on the formation of strategies for developing Ukrainian communities of new generations. It was noted that most leaders of Ukrainian communities are aware of the utopian and conflict-generating nature of the idea of creating a theocratic state in modern Ukraine.
\end{abstract}

Keywords: new religious movement, neocharismatics, new world order, theology of prosperity, theocratic state, public conflict.

Introduction

The relevance of the research problem for the study presented herein is concerned with the new challenges that arise for the Ukrainian community in the globalized world. Inter alia, postsecularism that has become deeply incorporated into Western society after the events of $9 / 11$, is often being "imported" into Ukraine together with the new religious movements. Supplementing local social and cultural context undergoes transformation, interconnects traditional and non-traditional religion, and takes on new forms. Bearing in mind a special role of new religious movements in deepening post-secular trends in Ukraine, it was underlined that public recognition of the inevitable non-confrontational coexistence of representatives of both traditional and 
new religious beliefs becomes particularly relevant herein.

New religious beliefs, which have become widespread in Ukraine since the 1970-1990-s, offer their own perspective of the sense of human life and the way of public life organization. They are based on some ideas and principles that encourage critical analysis by the society of the outlook and political strategies of its own further development.

Neo-charismatic groups become especially active and prominent among other new religious cults nowadays. It concerns, in particular, the International neo-charismatic movement "New Generation" with its branches now operating in many Ukrainian cities. In the Dnipropetrovsk Region, inter alia, the movement has its affiliated organizations in Mykolaivka, Nikopol, Novomoskovsk, Ordzhonikidze, Pavlohrad and Pershotravensk. Cult groups also operate in Odesa, Olevsk (Zhytomyr Region), Ochakiv (Mykolaiv Region), Lviv, Kyiv and other Ukrainian cities and towns. The organization celebrated its $30^{\text {th }}$ anniversary in 2019.

It is worth mentioning that the analysis of political ideology and activity of Ukrainian communities of the International charismatic movement "New Generation" will foster a better public understanding of profound principles and motivations of contemporary neo-charismatic religious movements in general. It will also help to reveal the negative aspects of their activity to prevent the destructive impact of neo-charismatic movements on the lives of Ukrainian people and the further evolution of the Ukrainian state.

The state of theme research shows that, though the International new religious charismatic movement "New Generation" is rather widespread in our country, no profound research on the topic has been carried out yet by our humani- tarian research school. Political and in particular theocratic ideas as the conflict aspects of dogma and the engagement of the movement representatives in Ukraine are not analyzed. Analytical studies worth paying attention to include research publications by N. Dudar, V. Yelenskyi, M. Zakhovich, A. Kolodnyi, L. Fylypovych and O. Yartys. These researchers developed new theoretical and methodological approaches to the analysis of new religious movements. The studies of L. Fylypovych (1998) are crucial for the coverage of the problem. She explored the mechanisms of the emergence of the new religion in comparison with the system of traditional religious values, dogma and religious relations and mentioned that the latter are not always able to satisfy the spiritual needs of a modern person. It is essential to note the studies of V. Yelenskyi (2002), who dedicated a certain amount of work to the status of religion in post-communist communities. I. Grabovska, T. Talko and T. Vlasova (2020) examined the influence of new religious cults on the formation of post-secularism in Ukraine. I. Grabovska and T. Talko (2015) analyzed the gender aspects of new religious dogma and drew attention to their intrinsic essentialism approaches to the solution of problems of marriage and family life. V. Rogatin (2016) referred to the positive and negative effects of new religious movements on the political life of the country. V. Voynalovych and N. Kochan (2014) investigated new religion in the context of its influence on ethnic political processes in Ukraine. Y. Yuvsechko (2015) described the impact of postmodernist paradigm on the state of contemporary religious evolution of the communities. The studies of the leading Ukrainian researcher of the charismatic movement "New Generation" V. Tytarenko $(2017$; 2009) are far-reaching, they define the peculiarities of a number of religious phe- 
nomena, inter alia: prophecies, charisma and charismatic leadership. In cooperation with A. Tyshchenko she analyzed the specific features of the organizational structure of the Ukrainian charismatic movement "New Generation" (Titarenko $\&$ Tishchenko, 2020), outlined the fundamental trends of the formation of modern charismatic theology (Tyshchenko \& Tytarenko, 2017).

The research was based on the fundamental indoctrination with the sermons and scientific works by the senior bishop of the Union of Ukrainian Orthodox Churches "New Generation" A. Tyshchenko, who devoted his studies to the history of the charismatic movement (Kolodnyy \& Tyshchenko, 2010), described the essence of modern charismatic theology (Tyshchenko, $2017^{\mathrm{a}}$ ). His publications on the impact of charismatic movements on the social and spiritual spheres of public life and the establishment of state-confessional relations in Ukraine are of particular interest (Tyshchenko, 2015-2016). He commended the influence of charismatic churches on the establishment of state-confessional relations in Ukraine (Tyshchenko, 2017 b), highlighted the main problems which arise in the sphere of aforementioned relations (Tyshchenko, $2017^{\circ}$ ). He also explored the particularities of the "New Generation" regional organizations and their development (Tyshchenko, 2018; ; Tyshchenko, $2018^{\mathrm{b}}$ ), examined the essence of charismatic leaders' political theology (Tishchenko, 2019; Tyshchenko, 2019). One of the most prominent researchers of the theological branch is M. Mokiyenko (2018), who drew a comparative analysis of the Pentecostal and Charismatic churches.

National researchers, who assess the activity of new religious movements as destructive, admit that it leads to the elimination of common lifestyle and spiritual and cultural values of a country, conflicts in ethnic confessional relations and degradation of the community. Some Ukrainian researchers tend to use more simplified thinking based upon unequivocal condemnation of new religious movements and call them "destructive totalitarian sects", with their worshippers being called "sectarians". The reasoning of such a simplified approach among the local humanists is the concern of the transformational process of the Orthodox outlook, which is traditional for the Ukrainian people. M. Davydun stresses that the Ukrainian society in a state of crisis and especially young generation are the frameworks for the emergence and rather successful activity of new religious sects. The researcher considers that modern young people, who are mainly socially disoriented, digest negative religious guidelines and demonstrate their inability to confront the sects' psychological influence. Moreover, the crisis in public existence and the absence of a socially acceptable way of employment opportunities given to young people hinder the process of their full-fledged socialization and lead to the state when a certain amount of them tend to assert themselves and reach selfrealization via quasi-religious practices. The scholar also highlights the fact that current legislation facilitates the dissemination of sects because the state itself cannot withhold their registration as far as they do not clearly declare antisocial positions or principles. Therefore, reconsideration of legislation in the sphere of religion becomes urgent because the state should have the ability to protect its citizens from any interference in their private life and mentality (Davydun, 2012).

The abovementioned opinions and warnings undoubtedly should be taken into consideration. When it comes to destructive totalitarian sects, all of the previously said is entirely true. 
Nevertheless, it is hard to agree with the inclusion of all new religious associations into totalitarian sects and the attempts to deal with the problem by silencing and preventing young people from getting acquainted with the essence of new religious guidelines and cults. It should be noted that representatives of the Orthodox Churches have been present in our universities for a long time, and the issue of the effectiveness of preventing the involvement of young people in sects by banning adherents of new religious cults in secondary schools is contradictory and, in fact, is a somewhat controversial solution to the problem. It appears to be a much better possibility that a qualified teacher interprets the fallacy of a presented doctrine than try to leave a young person uninformed, away from school or university on his own with a charismatic and artistic preacher of a new religious cult.

Quite interesting in terms of examining the problem are the studies of Russian and Belarusian scholars E. Balagushkin, V. Martinovich, Y. Ryzhov, who in particular established the relationship between the crisis periods of the community and the active spread of new religious movements. Belarusian researcher V. Martinovich (2015) devoted his in-depth analysis to the problem of migration of new religions. V. Ingovatov's (2018) research is devoted to post-secularism in relation to the value of human existence.

The study of the work of the founder of the "New Generation" movement O. Lediaev (1994; $2000 ; 2002$; 2005) became a necessary foundation upon which the analysis of the problem was built upon.

Particular attention in terms of understanding the peculiarities of the doctrine interpretation of the "New Generation" by representatives of the Orthodox tradition was given to a study by
V. Selivanovsky (2013) "Charismatic heresy. Analysis of the teachings of the religious organization "New Generation" in Blagoveshchensk".

Notable works by foreign researchers include the study of the influence of religious leaders on the growth of global Christianity by B. Christenson and R. V. Flori (2017); K. Resane's (2017) thoughts on the phenomenon of a miracle in the charismatic movement. Charismatic evangelical identity in terms of its transformation was considered by Francis Muller (Müller, 2015). Researchers of Allan Anderson (2013), John Weaver (2016) and Sarah Hinlicky Wilson (2016) became the pillar for understanding the essence of the charismatic transformation of Protestantism.

The aim of the research is to identify the conflict-generating potential of political ideas and strategies of the leaders of the neo-charismatic movement "New Generation".

Achieving the aim of the article requires the attainment of the following objectives:

- to define the semantic scope of the political theology of the charismatic movement "New Generation";

- to reveal the features of the implementation of political ideas in the activities of charismatic communities;

- to find the conflict aspects of the political theology of the "New Generation" and the ways of their neutralization.

The object of the research is the doctrine and cult activities of the International charismatic movement "New Generation".

The research subject is the theocratic ideas of the leaders of the "New Generation" and their influence on the political life of the Ukrainian community.

The research methods are used due to the principles that have become the most efficient in 
analysing conflict-generating aspects of political ideas and activity of the charismatic movement "New Generation". The principles of objectivity, tolerance, pluralism, historicism, impartiality, non-acceptance of tendentious interpretation of religious phenomena etc., determined the essence of the study. Since the principle of legal protection of freedom of conscience in the life of modern European communities is particularly important, it is advisable to use the following methods in studying the phenomenon of the neocharismatic movement "New Generation": a historical method that allows studying the cult in its origin, formation and development in the context of correlation between the societal development patterns and the specific circumstances of the movement formation; sociological method, through which it is possible to explore the charismatic movement as an object of external effects and at the same time the subject of influence on various social institutions. The study of the invariance and continuity of certain cult features was due to the typological method. The peculiarities of the new religious cult's reflection required specific philosophical methodologies, such as the ascent from abstract to concrete, the coincidence of historical and logical, dialectical and method of reconstruction, and phenomenological methodology.

An experiment. As part of the present research, students of several humanities faculties of the Oles Honchar Dnipro National University passed several tests. The experiment's essence was to find out the attitude of Ukrainian students to the theocratic ideas of the leaders of the "New Generation". A total of 134 answers were received to the question as follows: "Do you support the presence of representatives of the neocharismatic movement "New Generation", who promote theocratic ideas, in the Ukrainian state institutions?"

It turned out that none of the respondents supported the desire of leaders of charismatic movements to be present in the country's political institutions. The test results showed a negative attitude of young people towards the leaders of all neo-charismatic movements in Ukraine. They gave detailed explanations to their answers in tests.

Students consider the representatives of the aforementioned formations as scam artists whose moral qualities do not allow them to be present in the Ukrainian authorities. For example, one of the students in his post claimed that the "apostles" of the charismatic movement manipulate their followers' consciousness to enrich themselves. Therefore, all their ideas simply cannot be trustworthy. Student N. suggested that charismatic and new religious organizations in the Dnipropetrovsk region are second in terms of representation after the Orthodox Church, emphasizing that she condemned those who harm the life and health of individuals and society as a whole. From her point of view, charismatic leaders or any representatives of this movement are not needed in politics. Student S. wrote in the explanation of his position the following, "... I do not care about their views and beliefs, but I do care that these people are the bearers of ideology that the government will promote in our state". It was also mentioned that the idea of a theocratic state is obsolete for modern international politics. Then the predominance of one faith will infringe on the rights of other believers and violate current legislation. The statement that we did not need to have religious people in politics because of their irrational outlook gained ground. Student I. emphasized that he was against "...the promotion of these religious beliefs in public administration and public policy because politics must 
be rational in detecting and solving the problems of the state". 1

According to the results of this testing, an online discussion was held in order to clarify the opinion of students about the most theocratic ideas of the leaders of the "New Generation" and the possibility of creating a new type of society in the country on the basis of these ideas. The discussion was focused on the fact that a theocratic society is formed based on the supremacy of religious norms, and when all power in the state is in the hands of priests or clergy, and the head of such a state is the prominent leader of a religious group or church that holds power and claims for the role of the "God's Viceroy on Earth". Apart from that, it was emphasized that the leaders of the "New Generation" believe that it is possible to change the world through strict observance of biblical commandments and instructions. At the same time, many provisions of the Scripture are interpreted unconventionally, mainly in accordance with the "theology of prosperity".

A comprehensive discussion of this problem showed that students' attitude to the ideas of neo-charismatic leaders remained negative. Testing and further discussion clearly showed that the student youth, even without real experience of partaking in neo-charismatic communities, is deeply convinced of the manipulative nature of the attitude of leaders of quasi-religious groups to the members of their groups. There is an apparent parallel between the negative, manipulative practices of current political authorities in Ukraine and authoritarian, totalitarian leadership in neo-charismatic communities. It is emphasized that authoritarianism and the cult of the leader in neo-charismatic formations are generat-

1 Manuscript of tests. Archives of the author T. M. Talko. ed not exclusively with ideologies, strategies and practices of life organization imported mainly from the USA, but are primarily invoked by low personal culture and lack of high moral qualities of the majority of emerging "apostles-preachers", local charismatic leaders. A striking example is $V$. Muntyan, the founder of the Renaissance Church. Thus, students assess the neo-charismatic movement as a manifestation of sectarianism in general and call the leaders of this movement swindlers and rascals who, under the guise of God's name, try to take money out of the pockets of the Ukrainians for their own personal enrichment. Accordingly, the idea of creating a theocratic state in our area is considered a utopia, the possibility of which can be believed only by zombified members of neo-charismatic sects.

\section{The Main Part}

It should be noted that one of the essential signs of deepening post-secular trends in Ukraine is the institutionalization of new religious communities. Andriy Tyshchenko, the leader of the Ukrainian communities of the "New Generation", mentioned that a significant event for the Spiritual Administration of Evangelical Christians of the "New Generation" Ukrainian Christian Church was the decision of the State Committee for Religious Affairs to grant them the status of a denomination. Thus, in December 2006, the Ukrainian Christian Church "New Generation" received the highest registration status and became on a par with the Orthodox and Catholic Churches (Tishchenko, 2014, p. 22).

Researchers astutely observe that, despite the revivalist ideology, the mystification of doctrine and lack of a clear governance structure, in the beginning, the "New Generation" Church in Ukraine has become an influential mass organi- 
zation over the past 30 years whose spiritual and political activities significantly influence social, cultural and political processes in the country (Tytarenko, 2009; Titarenko \& Tishchenko, 2020, p. 28).

The church belongs to the so-called "apostolic movement" of the Euro-American tradition. It originated from Pentecostalism and Baptism. One should state that the governing structure of the "New Generation" Church is built on the episcopal principle and consists of five "Gifts of Service", which means that the governing body of the church is the apostle, prophet, evangelist, pastor and teacher. Scholars emphasize that according to this model of governance, the charisms of the "New Generation" copy the governing structures of the Roman Catholic Church. Accordingly, there is a projection of the idea of the highest spiritual authority of the Pope on its founder - "apostle" Oleksii Lediaev - which raises most of the problems of the movement. Lediaev created the first neo-charismatic community in Latvia in 1989. The lack of collegiality in governance led to authoritarianism and the cult of the leader. Gradually, the authoritarian personality of the pastor gained more weight from the followers than the original theological concept created by him. He is endowed with absolute power, solves personnel issues by himself and manages the church budget on his own. V. Tytarenko notes, "The charismatic church "New Generation"... is built on the "Revelation" by the founding pastor Oleksii Lediaev, which is brought into the life of separate religious communities. Thus, the concept of "baptism by a pastor" emerged and was finally formed. ...The pastoral vision and its embodiment by all members of the community are unquestionable..." (Tytarenko, 2009; Titarenko \& Tishchenko, 2020, p. 30).

Researchers identify several principles upon which the activities of charismatic churches are based. In particular, it is the principle of revivalism, constant modernization, constant quantitative and qualitative growth of the church, the principle of constant active participation of each member of society in the life of the church, constant pastoral care of each believer by his spiritual mentor (Tytarenko, 2009; Titarenko \& Tishchenko, 2020, p. 30).

It should be emphasized that not only at the start of its existence, but nowadays as well, the Ukrainian communities of the "New Generation" are under the influence of O. Lediaev, who formulated the basic doctrines of the "New Generation". He occasionally proclaims a "new revelation", which significantly changes the fundamental ideas of the doctrine. Thus, in the 1990s, Lediaev focused on the dissemination of teachings of the Word of Faith among his followers, and afterwards, he focused on the theology of prosperity. According to the essence of the latter, the adherents of the movement must be rich, successful and healthy, and this can be achieved through personal effort and devotion to their faith. V. Selivanovsky marks the differences between the theology of prosperity and the teachings of the Word of Faith. "The distinction between the theology of prosperity and the teachings of the Word of Faith can be explained by the categories of purpose (health and prosperity) and means (profession of faith). All leaders of the Word of Faith are at the same time the "teachers of prosperity", but not all "teachers of prosperity" are supporters of the Word of Faith (Selivanovskiy, 2013, p. 15). O. Lediaev, in his sermons, insists that God did not produce poverty. "All human beings were prosperous. Jesus became poor for us so that we could live in abundance", the pastor preaches (Ledyayev, 2019). The founder of the movement in 2002 was intro- 
ducing the ideology of the new world order. The "new world order" is based on the ideas of theocracy and active intervention in the world of politics. Researchers note that by initiating the foundation of a "theocracy" in Latvia, O. Lediaev tried to spread the ideas of the "new world order" in neighbouring countries, which was the reason for his ban from entering the Russian territory. While spreading his political theology in Ukraine among some other "deeds", he stipulated the ministry of the infamous pastor of the Embassy of the Blessed Kingdom of God for All Nations Sunday Adelaja, whose activities eventually became criminal and are now outlawed. 4,013 people were confirmed as deceived because of the pastor's activities. Some of the deceived committed suicide. The first president of Ukraine L. Kravchuk called the "pastor" a rascal. The Ukrainian Interchurch Council condemned the activities of the "Embassy of God". It is quite alarming that some domestic media started to talk about the possibility of the return of the "handsome pastor" and the new stage of preaching in order to fool and zombie people again.

One of the most fundamental became the ideas that are persistently repeated today in the sermons of the founder of the movement and his followers, establishing the pattern of a "new theology". They reflect not only the authoritarianism of the leader of the "New Generation" and his totalitarian thinking but also the political ambitions and aspirations of gaining political power, the focus on penetrating state political authorities. The theocratic transformation of the ideology of the "New Generation" began with the cultivation of loyalty to its leader and the prohibition of his criticism. O. Lediaev proclaimed, "Whoever protects the life, authority and dignity of his leader, he will be honoured. When our faith is depleted, we care only for ourselves, for our safety. Nevertheless, when our faith is reinforced by God's promises, we are able to protect, to care for those who are leading. If one reliably and faithfully fulfils the role of the second, then sooner or later God will give them the honour and authority of the first" (Ledyayev, 2010). Here are some more similar statements: "If you criticize a leader, you are blaspheming the divine right via whom the Holy Spirit speaks". The pastor takes himself seriously not just as a leader of the movement, but as a God's representative on Earth. He states that adherents must undergo the "Baptism into Moses", which will allow them to acquire the ability to unquestioningly love their "apostle" up to the level of identifying themselves with him, "The baptism into Moses is a mandatory moment of any pedagogy. Baptism is immersion, which means the identification of any disciple with his teacher. If a student is not baptized into a teacher, he is a bad student. Baptism into Moses is an emulation based on love. One will not be nice through violence. If a student loves his teacher, he will subconsciously "reproduce" his teacher. Here is how Paul the Apostle formulated his pedagogy's main postulate, "Imitate me as I imitate Christ". This is just the essence of the doctrine of the baptism into Moses" (Ledyayev, 2009ª).

Special worship practices of the "Toronto Blessing" have been introduced in the worship of this church. There are statements in the sermons that raise the question of whether a person is aware of the limits of what is allowed. For example, O. Lediaev stated, "Christ is our main coach, the standard of development of perfection". Proselytism is instilled and encouraged among the adherents as well. "We need to direct our people to serve. Bless your team to go and preach". A number of the pastor's statements testify to the attitude of the adherents of the "New 
Generation" to the conflict of relations not only with the traditional church, but also with society in general. In his sermon of June 30, 2019, the pastor said, "You should not preach the Church, you should only preach Jesus"; "Enemies are those who destroy your doctrines"; "New beginnings do not always look tolerant. One of the scandalous beginnings of Jesus Christ was that he did not bring peace but a sword. He did not ask - he fought. It is time to expel from the Church those who have created a den of robbers on its territory" (Ledyayev, 2019).

Theocratic ideas have been popular in O. Lediaev's sermons since 2012. Since then, the leader of the "New Generation" has been trying to subdue and control all pastors of the "New Generation" communities, demanding payment of tithings to the "mother" church. He declares, "The Church desperately needs money... Let us take our sacrifice and propose it in the name of new beginnings" (Ledyayev, 2019). The sermons insist that the believer should give the pastor $\$ 100$, and instead, according to the rule of retribution read by the pastor from the Bible, he will receive \$10,000 from God, multiplying his capital a hundredfold. If a believer presents an aircraft to a pastor, he will receive a fleet of aircraft from God (Selivanovskiy, 2013, p. 23). O. Lediaev claims that the head of an organization or church advertises (that is the word - advertises) his God. According to his prophecies, people will not go to church to a poor pastor who has no money car and lives in an old "Khrushchevbuilt" accommodation. He cannot offer them anything. Instead, the pastor promises his patronage. He declares, "Patronage is an attribute of any authority. Power means to control, while patronage means submission. If the husband is under the head of Christ, he is under the protection of the Lord and obeys Him. If the wife is under the head of the husband, then she is under the protection of the husband and obeys him. If children recognize the authority of their parents, they are under their protection, obeying their father and mother. The Father and I are one person. This is the main credo of patronage. The one who has seen Me has seen the Father, the one who has heard Me, has heard the Father: this is the way people who know what both physical and spiritual protection is thought (Ledyayev, $2009^{b}$ ).

Theocratic aspirations of the "apostle" of the "New Generation" are clearly stated in his reflections on democracy and liberalism. He emphasizes that the spirit of democracy, which merges with anarchy, humiliates today the secular life and church life. O. Lediaev, obviously imagining himself a political strategist of God, states that God never existed in a democracy. "God has always existed in a monarchy and a theocratic order", the preacher emphasizes. "And all churches involved in on democratic grounds will decline and disappear from Earth. Because God will respect only His laws" (Ledyayev, $2009^{c}$ ). He stresses his anti-liberal attitude, drawing parallels between an excellent demanding coach who overloads the athlete for the sake of his championship win and a bad - a liberal coach who is convenient for idlers. O. Lediaev talks about the need to establish God's kingdom on Earth, which is possible only through theocracy. He identifies theocracy with the "power of God" and insists that it is the most acceptable political strategy, the only thing that makes churches strong. "Theocracy" is "Divinity", says the "apostle". "When a leader obeys God, and his team obeys the leader, and everyone else obeys the team, then we can establish the Kingdom of God on Earth" (Ledyayev, 2005).

Ukrainian leaders of the "New Generation" 
note that "at the beginning of the XXI century a charismatic "political" theology was formed" (Tyshchenko, 2019, p. 189), emphasizing that an important part of their fundamental writings is the understanding of human rights and interpretation of Protestant denominations in political life. A. Tyshchenko notes that the separation of church and state does not prevent it from "getting involved in the development of social projects and their implementation". He emphasizes, "In general, we can say that the church wants to actively cooperate with both the state and public organizations in the social sphere. Today, the "New Generation" Churches in Ukraine are members of the Ukrainian Interchurch Council, and its representatives are members of the Council's governing bodies. It is worth mentioning that the social doctrines of modern Protestant churches have developed the principles of cooperation with society and the realization of each civic duty by each believer" (Tyshchenko, 20152016, p. 168). Pastor A. Tyshchenko points out not only thematic services and joint prayers for the well-being of the country as a whole and individuals who particularly need help as peculiarities of the church's activity. He emphasizes philanthropy for those in prisons, drug dens, hospitals, train stations and disadvantaged areas (Tishchenko, 2014, p. 23).

In 2014, an Internet channel of the movement was created. In 2016, the New Christian TV channel was launched, which has been issued a license for satellite broadcasting for a period of 10 years. A. Tyshchenko (2015-2016) notes, "The programs of the TV channel are aimed at the creative potential, spiritual revival of society, the promotion of Christian values, the formation of a positive reputation of Christian churches" (pp. 170-171). Emphasizing the need for constant development and modernization of church life, the leader of Ukrainian charismatic believers emphasizes, "Systematic changes in society and the formation of its "informational" image encourage the search for new ways of representing charismatic views in Ukrainian society. The newest information technologies, new forms of presence in and influence on the Ukrainian society via information platforms are used as well" (Tyshchenko, 2015-2016, p. 171).

\section{Conclusion}

The analysis of the sermons of the pastors of the "New Generation" and the ideas outlined in print and online publications leads to the conclusion of the formation of new motivational guidelines for believers, which can be defined through the concept of "profitability of belief". The sermons of the leaders of the neo-charismatic movement clearly present the signs of consumerist ethics; believers are suggested with motivational guidelines based upon the need to achieve economic success, the consumption of many goods and services as a positive thing, whereas thrift and austerity are considered to be erroneous ideas.

The active formation of charismatic political ideology dates back to the beginning of the XXI century. It is based on the ideas of O. Lediaev's "New World Order" and has signs of Christian extremism. The totalitarian nature of the "New Generation" community guidelines, the interpretation of biblical principles in a postmodernist way leads to ethical relativism, while the criticism of traditional religion leads to the aggravation of interreligious relations.

Leaders of the Ukrainian "New Generation" communities recognize that political strategies based on implementing the theocratic state ideas are utopian in modern Ukraine. The positive as- 
pects of their activity include mobility in reaction to important public events, focus on the movement modernization, education and interaction with the scientific community of the country, constant interaction with the Ukrainian Interchurch Council facilitate positive transformations of the charismatic movement political ideology.

The evolution of the charismatic movement "New Generation" in Ukraine is clear evidence of the deepening process of building a civilized democratic country, the embodiment of freedom of conscience and profound post-secular trends in public life.

\section{References}

Anderson, A. (2013). An Introduction to Pentecostalism: Global Charismatic Christianity. Cambridge: Cambridge University Press.

Christerson, B., \& Flory, R. (2017). The Rise of Network Christianity: How Independent Leaders are Changing the Religious Landscape. Oxford: Oxford University Press.

Davydun, M. A. (2012). Praktyka sotsial'no-pedahohichnoyi roboty shchodo profilaktyky destruktyvnykh relihiynykh vplyviv $u$ molodizhnomu seredovyshchi (Practice of Social and Pedagogical Work on Prevention of Destructive Religious Influences in the Youth Environment, in Ukrainian). Collection of Scientific Works of the Khmelnytsky Institute of Social Technologies of the University "Ukraine", 5, 58-60.

Fylypovych, L. O. (1998). Novi relihiyi Ukrayiny: poyava, typolohiya, perspektyvy (New Religions of Ukraine: Emergence, Typology, Prospects, in Ukrainian).
Religious Freedom: Historical Background, Legal Bases and Realities of Today, 2, 92-110.

Grabovska, I., Talko, T., \& Vlasova, T. (2020). New Religions as the Postsecular Epiphenomenon of Globalisation in the Contemporary Ukrainian Society. HTS Theological Studies, 76(1). Retrieved from https:/hts.org.za/index.php/hts.

Hrabovs'ka, I., Tal'ko, T. (2015). Psykhoanalitychni interpretatsiyi neokhrystyyans'kykh vchen' pro shlyub i sim"yu (Psychoanalytic Interpretations of neoChristian Teachings about Marriage and Family, in Ukrainian). In From Gender Ideologies to Discussions about the Modern Family (pp. 61-72). Dnipropetrovs'k: Makovetsky Publishing House.

Ingovatov, V. YU. (2018). Postsekulyarizm kak kontsept "novoy interpretatsii" tsennostnogo bytiya cheloveka (Post-Secularism as a Concept of a "New Interpretation" of Human Value Being, in Russian). Theology. Philosophy. Right, 3, 42-51.

Kolodny, A. (2010). Istoriya relihiyi v Ukrayini: u 10 t. T. 8: Novi relihiyi Ukrayiny (History of Religion in Ukraine: In 10 Volumes. Vol. 8: New Religions of Ukraine, in Ukrainian). Kyiv: Ukrainian Association of Religious Studies.

Kolodnyy, A., \& Tyshchenko, A. (2010). Kharyzmatychnyy rukh "Nove pokolinnya" (Charismatic movement "New Generation”, in Ukrainian). In History of Religion in Ukraine: In 10 Volumes. Vol. 8: New Religions of Ukraine (pp. 435450). Kyiv: Ukrainian Association of Religious Studies. 
Ledyayev, A. S. (1994). Kamen' pretknoveniya (The Stumbling Block, in Russian). Retrieved from http://logos-rhema.narod.ru/ledyayev books/stone.html.

Ledyayev, A. S. (2000). Vyzhit', chtoby zhit' (Survive to Live, in Russian). Retrieved from http://logos-rhema.narod.ru/ledyayev books/survive.html.

Ledyayev, A. S. (2002). Novyi mirovoi poryadok (New World Order, in Russian). Retrieved from http://www.gumer.info/bogoslov_Buks/protestant/Article/led novmir.php.

Ledyayev, A. S. (2005, January 17). Molitva o yedinoy strategii Dvizheniya "Novoye pokoleniye" (Prayer for a Unified Strategy of the New Generation Movement, in Russian). Retrieved from http://www.kingdomjc.com/Pritch/243.htm.

Ledyayev, A. S. (2009 ${ }^{b}$, April 27). Interv'yu. Internet-konferentsiya na "InVictory.org”. Ch. 3 (Interview. Internet Conference at "Interview". Part 3, in Russian). Retrieved from http://www.ng.lv/rus/novosti_mnenie pastora_pozicia cerkvi/interv u s pastorom alekseem ledaevim/?doc $=1522$.

Ledyayev, A. S. (2009', June 17). "Otdavayte Bozh'ye Bogu, a kesarevo kesaryu”, ("Give God to God, and Caesar's to Caesar", in Russian). Retrieved from http://www.ng.lv/rus/materiali/proekti aleksea_ledaeva/citati_pastora_aleksealedaeva/tema_12 teokratia_pokrovi tel stvo/.

Ledyayev, A. S. (2009a, April 4). Interv'yu, Internet-konferentsiya na "InVictory.org". Ch. 1 ("Interview". Internet Conference at "Interview". Part 1, in Russian). Retrieved from http://www.ng.lv- /rus/novosti_mnenie pastora pozicia cerkvi/interv u s pastorom alekseem ledaevim/?doc $=1520$.

Ledyayev, A. S. (2010, January 16). "Nadezhnye druz'ya" ("Reliable Friends", in Russian). (Video Material). Retrieved from https://www.youtube.com/watch?v=M Ct1SBcVYVo.

Ledyayev, A. S. (2019, June 30). Propoved' "Novye nachala" (Sermon "New Beginnings", in Russian). (Video Material). Retrieved from https://www.youtube.com/watch?v=ZrrTOw0XYi4.

Martinovich, V. A. (2015). Netraditsionnaya religioznost': vozniknovenie imigratsiya: Materialy $k$ izucheniyu netraditsionnoi religioznosti (Non-Traditional Religiosity: Emergence and Migration: Materials for the Study of Non-Traditional Religiosity, in Russian). (Vol. 1). Minsk: Minsk Theological Academy.

Mokiyenko, M. M. (2018). P'yatydesyatnytstvo ta khayzmatyzm: porivnyal'nyy analiz (Pentecostalism and chaism: A Comparative Analysis, in Ukrainian). Current Issues of Philosophy and Sociology, 1(21), 53-56.

Müller, F. (2015). Selbsttransformation und charismatisch evangelikale Identität: Eine vergleichende ethnosemantische Lebenswelt-Analyse. Frankfurt: Springer.

Resane, K. T. (2017). Miracles in the Neo-Charismatic Movement: Historical and Theological Critique. Verbum et Ecclessia, 38(1), 1-8.

Rogatin, V. N. (2016). Uchastiye neokhristianskikh religioznykh dvizhenii v sovremennoi politicheskoi zhizni Ukrainy (Participation of Neo-Christian Religious Movements in the Modern Political 
Life of Ukraine, in Russian). Scientific notes of Kazan University. Humanities Series, 158(3), 894-902.

Selivanovskiy, V. V. (2013). Kharizmaticheskaya yeres'. Analiz ucheniya religioznoy organizatsii "Novoye Pokoleniye" g. Blagoveshchenska (Charismatic Heresy. Analysis of the Teachings of the Religious Organization "New Generation" in Blagoveshhensk, in Russian). Blagoveshchensk: PKI “Zeya”.

Tishchenko, A. G. (2014). To, chto Vy mogli ne znat' o protestantskoy tserkvi (What You May not Know about the Protestant Church, in Russian). A New Generation, 8(23), 20-23.

Tishchenko, A. G. (2019). Formirovaniye politicheskoi teologii kharizmaticheskoi tserkvi: reaktsiya na proiskhodyashchee (Formation of the Political Theology of the Charismatic Church: Reaction to What Is Happening, in Russian). Colioquium-Journal. International Scientific Journal. Philology. Philosophical Science, 9(6), 42-47.

Titarenko, V. V., \& Tishchenko, A. G. (2020). Spetsifika organizatsionnoi struktury kharizmaticheskikh tserkvei v Ukraine: religiyevedcheskaya refleksiya (The Specifics of the Organizational Structure of Charismatic Churches in Ukraine: Religious Reflection, in Russian). Colioquium-Journal. International Scientific Journal. Philology. Philosophical Science, 7(59), 26-31.

Tyshchenko, A. H. (2015-2016). Vplyv kharyzmatychnykh rukhiv na sotsial'no dukhovnu sfery suspil'stva (na prykladi "Novoho Pokolinnya") (The Influence of Charismatic Movements on the So-
cio-Spiritual Sphere of Society (on the Example of the "New Generation"), in Ukrainian). Religious Freedom. 19: At the Crossroads of Epochs, Countries and Cultures, 167-171.

Tyshchenko, A. H. (2017 ). Formuvannya suchasnoyi kharyzmatychnoyi teolohiyi: sub"yektyvnyy faktor vplyvu (Formation of Modern Charismatic Theology: Subjective Factor of Influence, in Ukrainian). In Lyudyna, yaka reformuye $i$ reformuyet'sya. Materialy Vseukrayins'koyi naukovo-praktychnoyi konferentsiyi, prysvyachenoyi 500-littyu Reformatsiyi (A Man who Reforms and Is Reformed. Proceedings of the All-Ukrainian Scientific-Practical Conference Dedicated to the 500 ${ }^{\text {th }}$ Anniversary of the Reformation, in Ukrainian), (pp. 59-60). Kyiv: Igor Sikorsky Kyiv Polytechnic Institute.

Tyshchenko, A. H. $\left(2017^{\mathrm{b}}\right)$. Kharyzmatychni tserkvy $v$ konteksti utverdzhennya derzhavno-konfesiynykh vidnosyn v Ukrayini: problemy $i$ perspektyvy (Charismatic Churches in the Context of the Establishment of State-Confessional Relations in Ukraine: Problems and Prospects, in Ukrainian). In State and Church in the Modern History of Ukraine. Collection of Scientific Articles on the Materials of the VI All-Ukrainian Scientific Conference "State and Church in the Modern History of Ukraine" (October 25-26, 2017) (pp. 288296). Poltava: PP “Astraya”.

Tyshchenko, A. H. $\left(2017^{\circ}\right)$. Problemy i perspektyvy rozvytku derzhavno-konfesiynykh vidnosyn $v$ Ukrayini, cherez pryzmu sotsial'no-yevanhelizatsiynoyi diyal'no- 
sti kharyzmatychnykh tserkov (Problems and Prospects of Development of State-Confessional Relations in Ukraine, through the Prism of Social-Evangelistic Activity of Charismatic Churches, in Ukrainian). In $25^{\text {th }}$ Anniversary of Ukrainian Independence as a History of Religious Freedoms and Worldview Pluralism: State Institutions and Religious Organizations in Search of Partnership Models (pp. 402-410). Kyiv: Dukh I litera.

Tyshchenko, A. H. (2018). Lokal'nyy vplyv relihiynoho chynnyka na sotsial'no kul'turne seredovyshche mista (Local Influence of Religious Factor on the Socio-Cultural Environment of the City, in Ukrainian). In Kyiv Philosophical Studies. Proceedings of the scientific conference (Kyiv, May 17-18, 2018), (pp. 163-164). Kyiv: Borys Hrinchenko University of Kyiv.

Tyshchenko, A. H. (2018 $)$. Vplyv relihiynoho chynnyka na sotsial'ni zminy mista (naprykladi vplyvu diyal'nosti tserkvy "Nove pokolinnya", m. Pershotravens'k Dnipropetrovs'koyi oblasti) (Influence of a Religious Factor on Social Changes of the City (on an Example of Influence of Activity of Church "New Generation", Pershotravensk of the Dnepropetrovsk Area), in Ukrainian). Religion and Society, 1-2(29-30), 169175.

Tyshchenko, A. H. (2019). Formuvannya novoyi paradyhmy politychnoyi teolohiyi kharyzmatychnykh tserkov (na prykladi "Novoho pokolinnya") (Formation of a New Paradigm of Political Theology of Charismatic Churches (on the Example of the "New Generation"), in Ukrainian). Religion and Society, 1-2(33-34), 184-191.

Tyshchenko, A. H., \& Tytarenko, V. V. (2017). Osnovni tendentsiyi formuvannya suchasnoyi kharyzmatychnoyi teolohiyi (The Main Trends in the Formation of Modern Charismatic Theology, in Ukrainian). In Abrahamic Religions and the Reformation: The Formation of the Protestant Symbol of Faith and the Ideology of the New Social Reformation. European and Ukrainian Context of Identity). Proceedings of the scientificpractical conference (Halych, May 1819, 2017), (pp. 366-375). Halych: National Reserve "Ancient Halych".

Tytarenko, V. V. (2009). Kharyzmatyzm yak postmoderne khrystyyanstvo (Charisma as Postmodern Christianity, in Ukrainian). Ukrainian Religious Studies. Special issue 2, 151-162.

Tytarenko, V. V. (2017). Vid prorotstv u relihiyi do prohnozuvannya u relihiyeznavstvi: istoriya, teoriya, perspektyvy (From Prophecies in Religion to Prediction in Religious Studies: History, Theory, Perspectives, in Ukrainian). L'viv: Tsentr Yevropy.

Voynalovych, V. A., \& Kochan, N. I. (2014). Relihiynyy chynnyk etnopolitychnykh protsesiv na Donbasi: istoriya i suchasnist' (Religious Factor of Ethnopolitical Processes in Donbass: History and Modernity, in Ukrainian). Kyiv: Instytut politychnykh i etnonatsional'nikh doslidzhen' im. I. F. Kurasa NAN Ukrayiny.

Weaver, J. (2016). The New Apostolic Reformation: History of a Modern Charis- 
matic Movement. McFarland \& Company, USA.

Wilson, S. H. (2016). A Guide to Pentecostal Movements for Lutherans. Eugene: Wipf \& Stock.

Yelenskyi, V. Ye. (2002). Relihiya pislya komunizmu. Relihiyno-sotsial'ni zminy protsesi transformatsiyi tsentral'no skhidnoyevropeys; kykh suspil'stv: fokus na Ukrayini (Religion after Communism. Religious and Social Changes in the
Process of Transformation of Central and Eastern European Societies: Focus on Ukraine, in Ukrainian). Kyiv: NPU im. Drahomanova.

Yuvsechko, Ya. V. (2015). Postmodernists'ki tendentsiyi yak bazovyy chynnyk poshyrennya syntetychnykh neorelihiy (Postmodern Tendencies as a Basic Factor in the Spread of Synthetic Neoreligions, in Ukrainian). Current Issues of Philosophy and Sociology, 5, 173-176. 